\title{
ASSESSMENT OF PHYSICAL WORKING CAPACITY OF DIFFERENTLY TRAINED AND AGED FEMALE AEROBIC GYMNASTS
}

\author{
Roma Aleksandravičienè $\dot{1}^{1,2}$, Jovita Liaudeneckaitė ${ }^{3}$, \\ Ramunė Liaugminiené $\dot{1}^{1}$, Arvydas Siaurodinas ${ }^{1}$, Loreta Stasiulevičiené ${ }^{2}$ \\ Aleksandras Stulginskis University ${ }^{1}$, Kaunas, Lithuania \\ Lithuanian Academy of Physical Education ${ }^{2}$, Kaunas, Lithuania \\ Kaunas Vocational Training Centre for Business Specialists ${ }^{3}$, Kaunas, Lithuania
}

\begin{abstract}
Research background and hypothesis. Physical working capacity by $\mathrm{PWC}_{170}$ test allows estimating physical preparation of athletes' bodies, but these indices may not be directly linked to their sports achievements.

Research aim. The aim of this study was to identify and assess physical working capacity characteristics of differently trained and aged female athletes.

Research methods. The study included 40 subjects: young athletes (juniors) (12-14-years-old girls) and students of Lithuanian Academy of Physical Education - studying in aerobic gymnastics specialization. According to performance (training) level they were divided into the following groups: juniors $(\mathrm{n}=10)$, beginners $(\mathrm{n}=10)$, moderately trained $(n=10)$ and well-trained $(n=10)$ representatives of aerobic gymnastics. The testing included anthropometric measurements, heart rate (HR) measurements (HR values were recorded using heart rate measuring device "Sigma PC-15", Germany), and $\mathrm{PWC}_{170}$ tests. Athletes carried out two loads of physical activity at different intensities with a duration of 3 and 5 minutes (the rate of stepping (30 times per minute) was regulated according to the tempo of music that was specially prepared in the recording studio).

Research results. We found that the differences in physical working capacity between well trained gymnasts and the beginners were not statistically significant. We established similar values of $\mathrm{PWC}_{170}$ in moderately trained and junior groups; statistically significant difference $(\mathrm{p}<0.05)$ was established only comparing the latter two groups with well-trained athletes.

Discusion and conclussions. The results showed that physical working capacity of well trained aerobic gymnastics athletes (participating in international competitions, world and European Championships) had not reached very high training level, but they were assessed as adequately trained. Physical working capacity of beginners was satisfactory and the indices of moderately trained (with twice more training and competition experience) and junior athletes were very low.
\end{abstract}

Keywords: aerobic gymnastics, physical working capacity, $\mathrm{PWC}_{170}$, heart rate.

\section{INTRODUCTION}

A erobic gymnastics is a sport that requires the ability to perform high intensity aerobic movements with music combining them with the complex exercise of strength, jumps, flexibility and balance. Like other types of gymnastics, aerobic gymnastics requires aerobic and anaerobic endurance, very good flexibility, strength and excellent coordination. All these physical skills must be performed during the competition routine performing a complex of aerobic movements at high intensity and combining them with difficulty elements (jumps, dynamic, static strength and flexibility) without any intervals of rest (Aleksandravičiene, 2005). This sport is suitable for physically well- 
prepared individuals who develop not only physical abilities, but also improve the functional capacity of their and respiratory systems (Aleksandravičienè et al., 2004). Aerobic gymnastics is one of the newest branches of gymnastics, so the data on the physiological changes predominant in this kind of sports are extremely scarce in the special literature on the subject. Spanish scientists (Rodriguez et al., 1998) investigated elite aerobic gymnastics athletes (three of them were world champions), who performed their competition routines (individual, mixed pairs and trio) (Aerobic Gymnastics Code of Points 2009-2012, 2009). The heart rate and oxygen consumption were continuously recorded during exercise and recovery phase, as well as blood lactate concentration measured during recovery. It was established that some subjects' (lower level athletes) maximum aerobic capacity indices were higher than those of the top level athletes (world champions) and lactate concentration of some world champions was higher twice (from 9.4 to $20 \mathrm{mmol} / \mathrm{l}$ ).

The changes in heart rate values during specific competition routine of Lithuanian aerobic gymnasts were not significantly different from those of the world's elite $(99 \%$ of the maximum HR) athletes and reached $95 \%$ of the maximum HR (Aleksandraviciene, 2005). However, HR values of aerobic gymnasts during competitive activities were significantly higher compared to the HR values of artistic gymnastics athletes during competition exercise with the ball, their HR maximum was $88.2 \%$, and blood lactate concentration was only $4 \mathrm{mmol} / \mathrm{l}$ (Guidetti et al., 2000). This was mostly influenced by the structure - contest of competition routine, while the HR values at the beginning of routine in aerobic gymnastics and in artistic gymnastics had already reached a fairly high level. The gymnastics competitive routine is performed without rest intervals and fast increase in HR values at the beginning of routine is explained by some researchers by emotional stress and the fact that for athletes it is difficult to stand in a static position (posture) (Alexander, 1991). Some investigations in aerobic gymnastics activities were performed assessing energy consumption during competitive routine. Research found that about $50 \%$ of the total energy consumed during the competitive exercise was produced by aerobic ATP resynthesis (Aleksandravičienè, 2005).

We did not find any data assessing physical working capacity of female aerobic gymnastics athletes. At present telemetric systems are used to estimate aerobic capacity (Wideman et al., 1996;
Maiolo et al., 2003), but these devices not always can be used by many sports specialists. Therefore, $\mathrm{PWC}_{170}$ test was chosen to assess the physical working capacity, as it is also widely used in sports medicine centers, sports clubs testing the athletes in different kind of sports (Bloomfield et al., 1990).

The study carried out provides additional knowledge of physical working capacity of aerobic gymnastics athletes. Thus, the aim of this study was to identify and assess physical working capacity characteristics of differently trained and aged female aerobic gymnastics athletes.

\section{RESEARCH METHODS}

The subjects. The study included 40 subjects: young athletes (12-14-year-old girls) and students of the Lithuanian Academy of Physical Education studying in aerobic gymnastics specialization. According to performance (training) level they were divided into the following groups: juniors (training experience in aerobic gymnastics -3 years), beginners (training experience in aerobic gymnastics 1.5 year and no experience in competitions), moderately trained (athletes with experience in national competitions) and well trained representatives of aerobic gymnastics (members of the national team, who participated in world and European championships).

Experimental procedure. All participants were informed about the aim of the study. All subjects had no extra training on the day of testing. Before the testing all participants performed 5-minute specific warm up including low impact aerobics steps ant stretching exercises. The age and anthropometric characteristics of all the subjects are presented in Table 1 .

All subjects underwent two sessions of testing of physical activity of two different intensities with a duration of 3 and 5 minutes. All athletes were asked not to train vigorously on the evening before both tests. The first exercise included: $3 \mathrm{~min}$ stepping (the height of platform was $21.5 \mathrm{~cm}$ ) with the frequency of 30 times per minute. The rate of stepping (30 times per minute) was regulated according to the tempo of music that was specially prepared in the recording studio. The second exercise included stepping at the same frequency for 5 minutes (the height of the platform was $43 \mathrm{~cm}$ ). Between the first and the second physical activity the rest time interval of 3 minutes was allowed. Before the test, as well as after the first and the second physical activities HR values were 


\begin{tabular}{|l|c|c|c|c|}
\hline \multicolumn{1}{|c|}{$\begin{array}{c}\text { Groups of the } \\
\text { subjects }\end{array}$} & $\begin{array}{c}\text { Number } \\
\text { of the } \\
\text { subjects }\end{array}$ & $\begin{array}{c}\text { Age, years } \\
\text { (mean (SD)) }\end{array}$ & $\begin{array}{c}\text { Height, cm } \\
\text { (mean (SD)) }\end{array}$ & $\begin{array}{c}\text { Body mass, kg } \\
\text { (mean (SD)) }\end{array}$ \\
\hline Beginners & 10 & $19.8(0.75)$ & $168.3(4.24)$ & $59.2(5.94)$ \\
\hline $\begin{array}{l}\text { Moderately } \\
\text { trained }\end{array}$ & 10 & $21.5(1.21)$ & $164.7(5.04)$ & $56.5(4.90)$ \\
\hline Well-trained & 10 & $21.6(1.50)$ & $163.2(3.52)$ & $53.5(3.50)$ \\
\hline Young athletes & 10 & $13.1(1.79)$ & $155.1(9.97)$ & $46.1(9.86)$ \\
\hline
\end{tabular}

Table 1. Anthropometric characteristics and age of aerobic gymnasts

recorded using heart rate measurement device "Sigma PC-15", Germany).

According to the obtained data we calculated the indices of physical working capacity using the following formula (Raslanas, Skernevičius, 1998):

$$
P W C_{170}=N_{1}+\frac{\left(N_{2}-N_{1}\right)\left(170-f_{1}\right)}{\left(f_{2}-f_{1}\right)},
$$

where $\mathrm{N}_{1}$ - the first physical activity, $\mathrm{kgm} / \mathrm{min}$; $\mathrm{N}_{2}$ - the second physical activity, $\mathrm{kgm} / \mathrm{min} ; \mathrm{f}_{1}-\mathrm{HR}$ at the end of the first physical activity, beats/min; $f_{2}-H R$ at the end of the second physical activity, beats $/ \mathrm{min}$.

Further we determined $\mathrm{PWC}_{170}$ per kilogram of body weight:

$$
\frac{P W C_{170}}{k g},
$$

where $\mathrm{PWC}_{170}$ - physical working capacity; $\mathrm{kg}$ body weight.

Table 2. Evaluation of physical working capacity

\begin{tabular}{|l|c|}
\hline \multicolumn{1}{|c|}{ Rating } & PWC $_{\mathbf{~} 70}, \mathbf{~ k g m} / \mathbf{m i n} / \mathbf{k g}$ \\
\hline Very high training level & 25 and more \\
\hline High training level & $21-25$ \\
\hline Satisfactory training level & $16-20$ \\
\hline Low training level & $12-15$ \\
\hline Very low training level & less than 12 \\
\hline
\end{tabular}

Statistics calculations. The data were calculated using computer programs Microsoft Excel and Statistica for Windows 5.0. Descriptive data are presented as mean and standard deviation. Arithmetic averages of measurements were compared using the nonparametric Wilcoxon test and Student's t test. The level of significance was set at 0.5 .

\section{RESEARCH RESULTS}

We established that the highest heart rate preexercise period $\left(\mathrm{HR}_{\text {pre-exercise }}\right)$ was in the group of beginners 107.9 (11.1), while in the junior group it was $103.5(8.6)$ beats/min and $\mathrm{HR}_{\text {pre-exercise }}$ of moderately trained athletes was 98.7 (8.9) beats/ min, the differences among these groups were not statistically significant $(p>0.05)$. Statistically significant difference $(\mathrm{p}<0.05)$ of $\mathrm{HR}_{\text {pre-exercise }}$ was found between well-trained gymnasts (91.4 (8.0) beats/min.) and beginner athletes. The HR values after 3 minutes of stepping exercise of well trained group (138.8 (14.0) beats $/ \mathrm{min})$ were statistically significantly lower $(p<0.05)$ than those in other three groups. The HR after first physical load was almost identical in junior (162.7 beats/min) and beginner groups $(161.2$ beats $/ \mathrm{min})$ and it slightly differed from moderately trained athletes (166.5 beats $/ \mathrm{min}$ ). The results showed that HR values after the second physical load (5 minutes of stepping exercise) were not statistically different $(p>0.05)$ between beginners and well trained athletes and they were respectively $-160.8(9.0)$ beats/min and 166 (21.3) beats $/ \mathrm{min}$. HR values of well-trained athletes (after 5 minutes physical load) were statistically significantly lower $(\mathrm{p}<0.05)$ than moderately trained athletes (183.18 (13.7)) and juniors (192 (18.4)). The HR of beginners athletes after the first and second physical loads were similar (respectively 161 (21.3) and 166.5 (16.3) (Figure 1).

The results showed that HR recovery values after 5-minutes exercise were lower in the group of well-trained aerobic gymnastics athletes (100.6 (6.9) beats $/ \mathrm{min}$ ) and they statistically significantly differed $(p<0.05)$ from those in the other three gymnast groups. The HR recovery values of beginners, moderately trained and junior athletes were similar and the differences between them were not statistically significant $(p>0.05)$ (respectively were 113.8 (11.8) beats/min, 116.9 (10.7) beats/min and 120.3 (9.4) beats/min) (Figure 2).

Physical working capacity was established using $\mathrm{PWC}_{170}$ test. We found that the difference between well-trained and beginner athletes was not statistically significant $(\mathrm{p}>0.05)$ (welltrained athletes' $\mathrm{PWC}_{170}$ was 22.0 (3.5) $\mathrm{kgm} / \mathrm{min}$ ), beginners' group $-15.8(5.5))$. We found similar 
Figure 1. HR values of aerobic gymnastics athletes during the first minute of recovery, 3 minutes and 5 minutes after physical load

Note. * - statistically significan difference $(\mathrm{p}<0.05) ; *$ - statistically significant difference $(p<0.05)$ compared to other three groups.

Figure 2. HR values of aerobic gymnastics athletes during recovery

Note. $* *$ - statistically significant difference $(\mathrm{p}<0.05)$ compared to other three groups.

Figure 3. The indices of physical working capacity of aerobic gymnastics athletes (per kilogram of body weight)

Note. $*$-statistically significant difference $(\mathrm{p}<0.05)$.
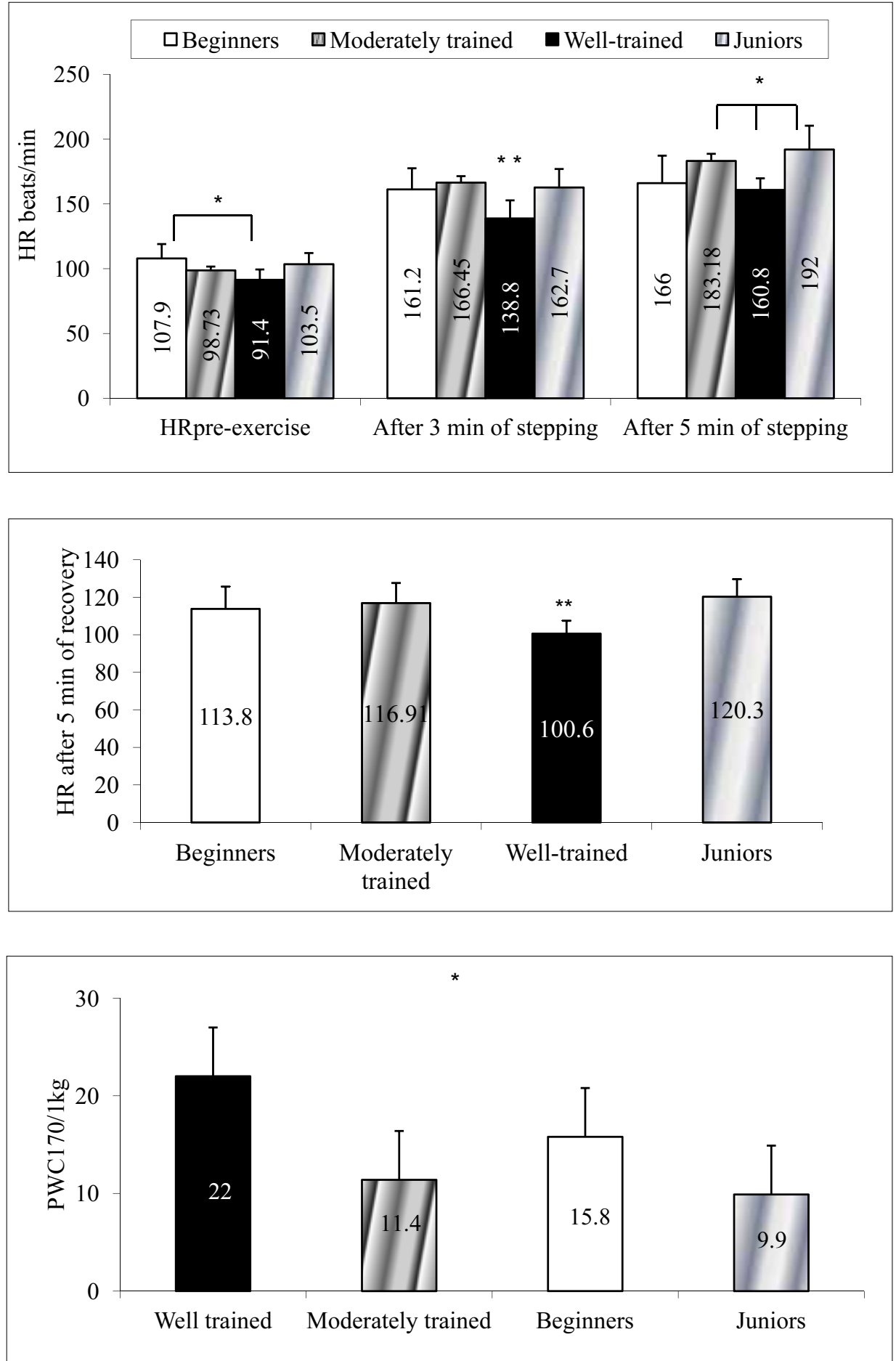

values of $\mathrm{PWC}_{170}$ in moderately trained and junior groups: there were 11.4 (5.5) $\mathrm{kgm} / \mathrm{min}$ and 9.9 (4.3) $\mathrm{kgm} / \mathrm{min}$. The statistically significant difference $(p<0.05)$ was established only comparing these two groups with well-trained athletes (Figure 3).

\section{DISCUSSION}

The present study was aimed to identify and assess physical working capacity characteristics of aerobic gymnastics athletes. As we expected, the lower $\mathrm{HR}_{\text {pre-exercise }}$ was in well-trained aerobic gymnastics group, but it was not significantly different from beginner group. It was established that HR values after both physical loads (3- and 5-minute stepping exercise of the same intensity) increased by $50 \%$ and more in all groups. There was hardly any difference in the relative means of HR after the first physical load, when the highest value in the moderately trained group reached $68.6 \%$. The highest HR values after the second physical load (as we expected) were in junior group. 
It may be explained by higher heart rate of children which is variable and depends on the child's age (Saris, 1985). However, the HR relative changes after 5-minute stepping exercise of young athletes coincided with those of the well-trained gymnasts and reached $85.5 \%$. It was probably influenced by the fact that before taking up aerobic gymnastics well-trained athletes might have been practicing artistic gymnastics for a number of years. Besides, it is known that aerobic capacity of representatives of aerobic gymnastics is by $25 \%$ higher than the normative values of girls at similar age, but it is considerably (about 35\%)) lower than the respective indices of athletes developing endurance (Aleksandravičienè, 2005). The results of our study do not coincide with the findings of other authors claiming that after regular classes in aerobics gymnastics there is a significant decrease in the HR of women going in for sports (Garber et al., 1992).

At present, telemetric systems are used to estimate aerobic capacity (Wideman et al., 1996; Maiolo et al., 2003), but these devices not always can be used by many sports specialists. Therefore, $\mathrm{PWC}_{170}$ test was chosen to assess the physical working capacity as it is also widely used in different kinds of sports (Bloomfield et al., 1990). In our research HR was recorded during the recovery after two stepping loads. The results show that the best recovery was in well-trained gymnasts' group. This confirms the results of other authors who argue that endurance training improves maximal oxygen consumption, increases the working muscle capillary network, reduces the heart rate during exercise at the same intensity (Kubukeli et al., 2002). It was found that after strenuous exercise HR decreases to a level that is higher than it was before the exercise. It depends on the duration of exercise intensity: the heavier the load, the longer the recovery. In our study, in beginner and moderately trained groups HR recovery values were quite close to the $\mathrm{HR}_{\text {pre-exercise. }} \mathrm{HR}$ during recovery in junior group was the highest, but the relative values were similar to those in moderately trained group (60 and 56\%).

It is known that physical working capacity $\left(\mathrm{PWC}_{170}\right)$ depends on athlete's sports activity. The findings of other authors (Svannshvili et al., 2009) established that the $\mathrm{PWC}_{170}$ of athletes in cyclic kinds of sports was $21.8(0.6)$. In our research we found similar values of physical working capacity in the group of well-trained subjects where $\mathrm{PWC}_{170}$ was 22.0 (6.1). But these results were lower compared to those of endurance-trained athletes $\left(\mathrm{PWC}_{170} 23.1\right.$ (4.1) $\left.\mathrm{kgm} / \mathrm{min}\right)$ and higher than those of speed-power trained athlete's $\left(\mathrm{PWC}_{170}\right.$ $20.3(2.8) \mathrm{kgm} / \mathrm{min})$.

Our results indicated that physical working capacity of moderately trained and junior gymnasts were similar. We did not establish any statistically significant differences of physical working capacity of moderately trained ( $\mathrm{PWC}_{170} 11.4$ (5.9), beginner and junior aerobic gymnastics athletes $\left(\mathrm{PWC}_{170}\right.$ 9.9 (5.4)) while in the beginner group, the $\mathrm{PWC}_{170}$ indices were about $30 \%$ higher (15.8 (6.3)) than those in the other two groups.

Results of our study confirm the hypothesis that physical working capacity by $\mathrm{PWC}_{170}$ test allows estimating physical preparation of athletes' bodies, but these indices may not be directly linked to their sports achievements.

\section{CONCLUSIONS AND PERSPECTIVES}

The results showed that physical working capacity of well-trained aerobic gymnastics athletes (participating in international competitions, world and European championships) had not reached very high training level, but they were assessed as adequately trained. Physical working capacity of beginner gymnasts was satisfactory and the indices of moderately trained (with twice more training and competition experience) and junior athletes were very low.

\section{REFERENCES}

Aerobic Gymnastics Code of Points 2009-2012. (2009). Federation Internationale de Gymnastique.

Aleksandravičienè, R. (2005). Skirtingo amžiaus ir treniruotumo moteru fiziologiniai pokyčiai ir energetika aerobikos pratimu metu: daktaro disertacija. Kaunas: Lietuvos kūno kultūros akademija.

Aleksandravičienè, R., Stasiulis, A., Zaičenkovienè, K., Liaugminienè, R. (2004). Skirtingo amžiaus moteru aerobinis pajègumas specifinio fizinio krūvio metu. Ugdymas. Küno kultūra. Sportas, 2 (52), 3-7.

Alexander, M. J. L. (1991). Physiological characteristics of elite and subelite rhythmic gymnastics. Journal of Human Movement Studies, 20, 99-127.

Bloomfield, J., Blanksby, B. A., Ackland, T. R. (1990). Morphological and physiological growth of competitive swimmers and non-competitors through adolescence. 
The Australian Journal of Science and Medicine in Sport, 22, 4-12.

Garber, C. E., McKinnry, J. S., Carleto. R. A. (1992). Is aerobic dance an effective alternative to walkjog exercise training? Journal of Sports Medicine \& Physical fitness, 32 (2), 136-141.

Guidetti, L., Baldari, C., Capranica, L., Persichini, C., Figura, F. (2000). Energy cost and energy sources of ball routine in rhythmic gymnasts. International Journal of Sport Medicine, 21 (3), 205-209.

Kubukeli, Z. N., Noakes, T. D., Dennis, S. C. (2002). Training techniques to improve endurance exercise performances. Sports Medicine, 32 (8), 489-509.

Maiolo, C., Melchiorri, G., Iacopino, L., Masala, S., DeLorenzo, A. (2003). Physicalactivityenergyexpenditure measured using a portable telemetric device in comparison with a mass spectrometer. Journal of Sports Medicine, 37 (5), 445-447.

Raslanas, A., Skernevičius, J. (1998). Sportininku testavimas. Vilnius: LTOK.

Rodriguez, F. A., Iglesias, X., Marina, M., Fado, C. (1998). Physiological demands of elite competitive aerobics. Journal of Sports Science, 16, 510-511.

Saris, W. H. (1985). The assessment and evaluation of daily physical activity in children. Acta Paediatrica Scandinavica Supplement, 318, 37-48.

Svannshvili, R.A., Sopromadze, Z. G., Kakhabrishvili, Z. G. et al. (2009). Athletes physical working capacity. Georgian Medical News, 166, 68-72.

Wideman, L., Stoudemire, N. M., Pass, K. A. et al. (1996). Assessment of the Aerosport TEEM 100 portable metabolic measurement system. Medicine \& Science in Sports \& Exercise, 28, 509.

\title{
SKIRTINGO MEISTRIŠKUMO IR AMŽIAUS AEROBININKIŲ FIZINIO DARBINGUMO VERTINIMAS
}

\author{
Roma Aleksandravičien $\dot{e}^{1,2}$, Jovita Liaudeneckaité $\dot{e}^{3}$, \\ Ramunė Liaugminiené ${ }^{1}$, Arvydas Siaurodinas ${ }^{1}$, Loreta Stasiulevičienė² \\ Aleksandro Stulginskio universitetas ${ }^{1}$, Kaunas, Lietuva \\ Lietuvos kūno kultūros akademija², Kaunas, Lietuva \\ Kauno paslaugu verslo darbuotoju profesinio rengimo centras ${ }^{3}$, Kaunas, Lietuva
}

\section{SANTRAUKA}

Tyrimo pagrindimas ir hipoteze. Fizinio darbingumo nustatymas taikant $\mathrm{PWC}_{170}$ testą leidžia ivertinti sportininko organizmo fizini pasirengima, tačiau šie rodikliai ne visada turi tiesiogini ryši su sportiniais rezultatais.

Tikslas - nustatyti ir ivertinti skirtingo meistriškumo ir amžiaus aerobininkių fizini darbinguma.

Metodai. Buvo tiriama 40 respondenčiu: jaunosios sportininkès (jaunès - 12-14 m. mergaitès) ir Lietuvos kūno kultūros akademijos studentès - aerobinès gimnastikos specializantès. Tiriamosios pagal meistriškumą buvo suskirstytos į šias grupes: jaunosios sportininkès (jaunès) $(n=10)$, pradedančiosios $(n=10)$, pažengusios, $(n=10)$ ir didelio meistriškumo $(\mathrm{n}=10)$. Testavimo metu atlikti antropometriniai matavimai, pulsometrijos ir $\mathrm{PWC}_{170}$ testai. Taip pat buvo atliekami du skirtingo intensyvumo fiziniai krūviai, kurių trukmè - 3 ir 5 minutès (laipiojimo tempas (30 kartu per minutę) buvo reguliuojamas pagal muzikos greiti).

Rezultatai. Fizinio darbingumo rodikliai tarp didelio meistriškumo ir pradedančiuju aerobininkiu statistiškai reikšmingai nesiskyrè. $\mathrm{PWC}_{170}$ reikšmès panašios pažengusiujų ir jaunių grupese, statistiškai reikšmingas skirtumas $(\mathrm{p}<0.05)$ buvo nustatytas tik lyginant pastarąsias dvi grupes su didelio meistriškumo sportininkèmis.

Aptarimas ir išvados. Rezultatai rodo, kad didelio meistriškumo aerobininkių (dalyvaujančiu tarptautinèse varžybose, pasaulio ir Europos čempionatuose) fizinio darbingumo rodikliai nebuvo labai geri, o atitiko tik gerą treniruotumo vertinimą. Tuo tarpu pradedančiujų aerobininkių fizinio darbingumo rodikliai buvo geresni negu pažengusiujų sportininkių, turinčių dvigubai didesnį treniruočių stažą ir varžybinę patirti. Pažengusiujų ir jaunujų sportininkių, turinčių toki patị treniruočių stažą, fizinis darbingumas statistiškai reikšmingai nesiskyrè ir atitiko mažą treniruotumą.

Raktažodžiai: aerobinè gimnastika, fizinis darbingumas, $\mathrm{PWC}_{170}$, širdies susitraukimų dažnis.

Gauta 2012 m. birželio 21 d.

Received on June 21, 2012

Priimta 2012 m. rugsèjo $7 \mathrm{~d}$.

Accepted on September 7, 2012
Corresponding author Roma Aleksandravičienè

Lithuanian Academy of Physical Education

Sporto str. 6, LT-44221 Kaunas

Lithuania

Tel +37068636488

E-mail romanellagrande@gmail.com 